Green, H. N. (1943). Lancet, 245, 147.

Green, H. N. \& Stoner, H. B. (1947). Brit. J. exp. Path. 28, 189.

Green, H. N., Stoner, H. B. \& Bielschowsky, M. (r 949). F. Path Bact. 6r, ror.

Green, H. N., Stoner, H. B., Hiteley, H. J. \& Elgin, D. (r949). Clin. Sci. 8, nos. I and 2.

Gribble, M. de G., Peters, R. A. \& Wakelin, R. W. (1947). Y. Physiol. ro6, 36 .

Grossman, C. M., Sappington, T. S., Burrows, B. A., Lavietes, P. H. \& Peters, J. P. (1945). J. clin. Invest. 24, 523 .

Hallberg, L. (1950). Lancet, 258, $35 \mathrm{I}$.

Hirshfeld, J. W., Abbott, W. E., Pilling, M. A., Heller, C. G., Meyer, F., Williams, H. H., Richards, A. J. \& Obi, R. (1945). Arch. Surg. 50, 194.

Homburger, F. (1948). Amer. J. Med. 5, 264.

Howard, J. E., Parson, W., Stein, K. E., Eisenberg, H. \& Reidt, V. (1944). Johns Hopk. Hosp. Bull. 75 , I56.

Howard, J. E., Winternitz, J., Parson, W., Bigham, R. S. Jr. \& Eisenberg, H. (1944). Yohns Hopk. Hosp. Bull. 75, 209 .

Ingle, D. J., Ward, E. O. \& Kuizenga, M. H. (1947). Amer. Y. Physiol. 149, 5 ro.

Keys, A. (1944). Conference on Metabolic Aspects of Convalescence Including Bone and Wound Healing. Transactions of the Seventh Meeting, p. 90 . New York: Josiah Macy Jr. Foundation.

Keyser, J. W. (1948). Ann. Surg. 127,605.

Kremen, A. J. (1948). Surgery, 23, 92.

Li, C. H. (1950). Brit. med. Y. i, 299 .

I cong, C. N. H. (1947). Recent Progr. Hormone Res. r, 99.

Lucido, J. (1940). Ann. Surg. I r. 640.

Lund, C. C. \& Levenson, S. M. (1945). F. Amer. med. Ass. 128, 95.

Madden, S. C. \& Clay, W. A. (1945). F. exp. Med. 82, 65.

Meyer, F. L., Hirshfeld, J. W. \& Abbott, W. E. (1947). Y. clin. Invest. 26, 796.

Mulholland, J. H., Co Tui, F. W., Wright, A. M. \& Vinci, V. J. (1943). Ann. Surg. I17, 512.

Munro, H. N. \& Chalmers, M. I. (1945). Brit. J. exp. Path. 26, 396.

Munro, H. N. \& Cuthbertson, D. P. (1943). Biochem. J. 37, xii.

Noble, R. L. \& Toby, C. G. (1948). Y. Endocrinol. 5, 303.

Peters, J. P. (1944). Fed. Proc. 3, 197.

Peters, J. P. (1946). Ann. New York Acad. Sci. 47, 327.

Peters, J. P. (1948). Amer. F. Med. 5, 100.

Rose, W. C. (1949). Fed. Proc. 8, 546.

Sellers, E. A. \& Best, C. H. (1947). Brit. med. F. i, 522.

Selye, H. (1949). Textbook of Endocrinology, and ed. Montreal, Canada: Acta Endocrinologica Inc.

Stevenson, J. A. F. \& Bensley, E. H. (1947). Lancet, 252, 568.

Stevenson, J. A. F., Schenker, V. \& Browne, J. S. I. (1945). F. Canad. med. Serv. $2,345$.

Stewart, C. P., Learmonth, J. R. \& Pollock, G. A. (1941). Lancet, 240, 818.

Stoner, H. B. \& Green, H. N. (1947). Brit. Y. exp. Path. 28, 127.

Stoner, H. B. \& Green, H. N. (1949). F. Path. Bact. 61, 114.

Taylor, F. H. L., Levenson, S. M., Davidson, C. S. \& Adams, M. A. (1943). New Engl. J. Med. $229,855$.

Taylor, F. H. L., Levenson, S. M., Iavidson, C. S., Browder, N. C. \& Lund, C. C. (1943). Ann. Surg. 18,2 I 5 .

Trueta, J., Barclay, A. E., Danicl, P., Franklin, K. J. \& Prichard, M. M. L. (1946), Lancet, 25 r, 237.

Varco, R. L. (1946). Surgery, r9, 303.

Varco, R. L. (1947). Surg. Gynec. Obstet. 84, 611.

Venning, F. H., de Vries, J. A. \& Herbert, P. H. (1947). Conference on Metabolic Aspects of Convalescence. Transactions of the Sixteenth Meeting, p. I 46 . New York: Josiah Macy Jr. Foundation.

Werner, S. C. (1948). Amer. Y. Med. 5, 749.

Werner, S. C., Habif, D. V., Randall, H. T. \& Lockwood, J. S. (1949). Ann. Surg. 130, 688.

Whipple, G. H. \& Madden, S. C. (r944). Medicine, 23, 2 I5.

White, A. \& Dougherty, T. F. (1946). Ann. N.Y. Acad. Sci. 46, 859.

Young, N. F. (1948). Amer. F. Med. 5, 586 .

\title{
Diet and Inborn Errors of Metabolism
}

\section{By C. Rimington, Department of Chemical Pathology, University College Hospital Medical School, University Street, London, W.C. I}

The title of my communication imposes upon me rather severe restrictions as to subject. Inborn errors are gene-controlled deviations from the normal and are almost 
certainly expressions of the absence from the affected organism of one or more enzymes. Those that have been encountered and studied in man and animals are, for the most part, relatively harmless, or at any rate non-lethal, aberrations and, being genetically controlled, are unlikely to be influenced by external conditions such as diet, except, possibly, in a quantitative manner. They may be physically striking as is, for example, albinism due to the absence of the enzyme system responsible for melanin production, and familial methaemoglobinaemia which imparts a slaty colour to the sufferer, or they may be of such a character as to go unnoticed for years. Alcaptonuria and cystinuria may easily be overlooked in this way.

Relatively few studies have been made of any effect exerted by diet upon metabolic errors except for those upon the metabolism of the aromatic amino-acids and, in recent years, investigations upon cystinurics. I shall confine myself mainly, therefore, to a discussion of these conditions and of related, experimentally produced metabolic errors. Familial methaemoglobinaemia is also a condition of interest because the specific biochemical lesion has been identified and because it may be influenced by the administration of ascorbic acid or of methylene blue. The latter substance, it is true, must be regarded as a drug rather than as an article of diet, but it forms an effective substitute for the missing coenzyme in the red cell.

Such conditions as diabetes and gout might possibly be regarded as metabolic errors and therefore suitable for inclusion in this review but I feel that they are in themselves such big subjects and that so little is really known concerning their relation to diet that it would be more prudent to exclude them. I have also decided to exclude all errors induced in an organism by diet but not referable to an inborn genetic constitution. No account will thus be taken of the effects of carcinogens or of chemically induced mutations, of vitamin deficiencies or of antivitamins like the Chastek-paralysis factor. Nor will I engage upon the theme, however attractive, of the phenomenon of adaptation by micro-organisms, the developments of new metabolic pathways in response to the presence of a nutrient, previously unfamiliar to that organism.

\section{Cystinuria}

I begin with cystinuria. In this familial disease, which is possibly inherited as a dominant character, the amino-acid, cystine, is present in quantities much greater than normal in the urine, from which it may be crystallized by appropriate treatment. Garrod (1923) clearly regarded it as an example of arrested metabolism, the subject being supposedly unable to oxidize cystine in the normal way. Even at that time it was known that the urine frequently contained other amino-acids and also the diamine bases, cadaverin and putrescin, in addition to cystine and no explanation could be offered of this fact. Later it was found by Brand, Cahill \& Harris (I935) that the giving of cystine to a cystinuric did not raise the output of cystine in the urine, although such a rise did occur after the administration of either cysteine or the other sulphur-containing amino-acid, methionine. Again, it had been observed by Abderhalden (1903) that the post-mortem examination of an infant that died at the age of 21 months with symptoms of inanition, revealed the presence of innumerable white specks, shown to be deposits of crystalline cystine, on the surface of the internal organs. The child belonged to 
a family which included several cystinurics and, although the presence of cystine in the urine was never demonstrated, this was assumed, also, to be a case of cystinuria. Garrod (1923) comments that in the few other available records of post-mortem examination of cystinurics, no mention is made of such deposits of cystine in the tissues.

'The whole subject presented a picture of confusion which only began to be dispelled when the technique of partition chromatography became available for the study of pathological urines. Using this powerful tool, Dent (1949) showed that there is a normal pattern of amino-acids present in urine (see Fig. I) but that in certain conditions the

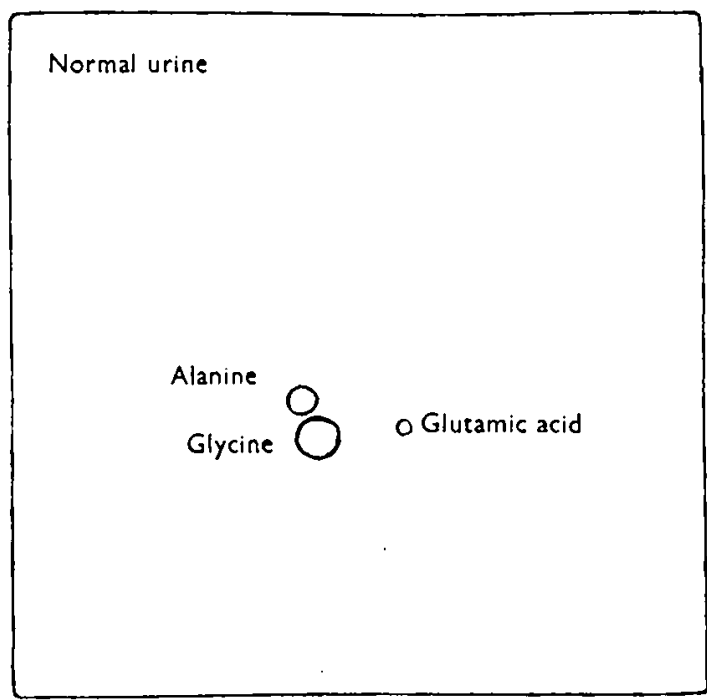

Fig. I

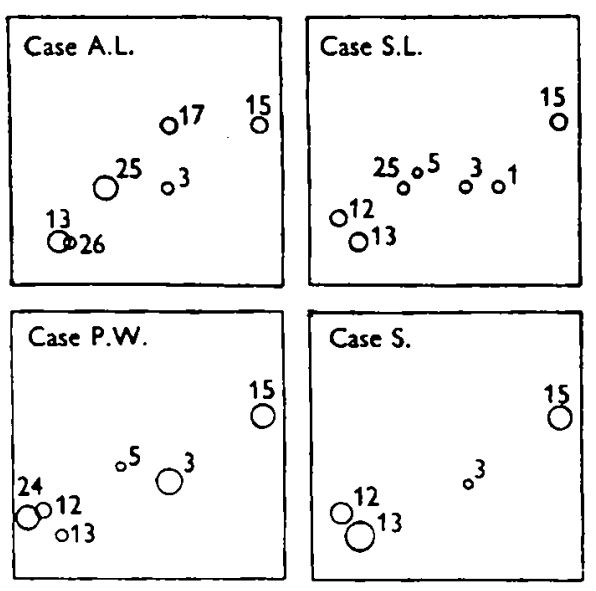

Fig. 2

Fig. I. Partition chromatogram of amino-acids in normal urine.

Fig. 2. Partition chromatograms of amino-acids in four cystinuric urines. From Dent (r949). I, glutamic acid; 3, glycine; 5 , alanine; 12, arginine; 13 , lysine; 15 , cystine; 17, taurine; 24 , unknown, possibly cadaverine or putrescine; 25 , unknown; 26 , ornithine.

renal threshold appears to be lowered with a consequent amino-aciduria. Examples of such are the Fanconi syndrome and hepatolenticular degeneration. In the Fanconi syndrome the blood amino-acid nitrogen is within normal limits and the excretion of amino-acids in the urine, including cystine, seems definitely to be due to defective tubular reabsorption. The reabsorption of phosphate and glucose is also impaired. This condition has almost certainly been confused at times with true cystinuria, in which the failure of tubular reabsorption is confined to certain, particular, structurally similar amino-acids. Dent has found that in cystinuria also the plasma amino-nitrogen level is not raised, and chromatography shows the amino-acid pattern to be normal, there being no excess of cystine. In the urine, however, the amino-acid pattern is very far from normal, lysine constantly accompanying cystine in concentrations up to twenty times the usual value (Fig. 2). It is of interest that the pattern of abnormality varies somewhat from case to case, but is relatively constant for any one individual. 
Dent's (1949) suggestion is that cystinuria must be regarded as a renal abnormality, a condition of ineffective tubular reabsorption affecting only certain amino-acids, which are presumably reabsorbed by the same group of tubular cells. The structural similarity between the substances affected is very striking (Fig. 3 ).

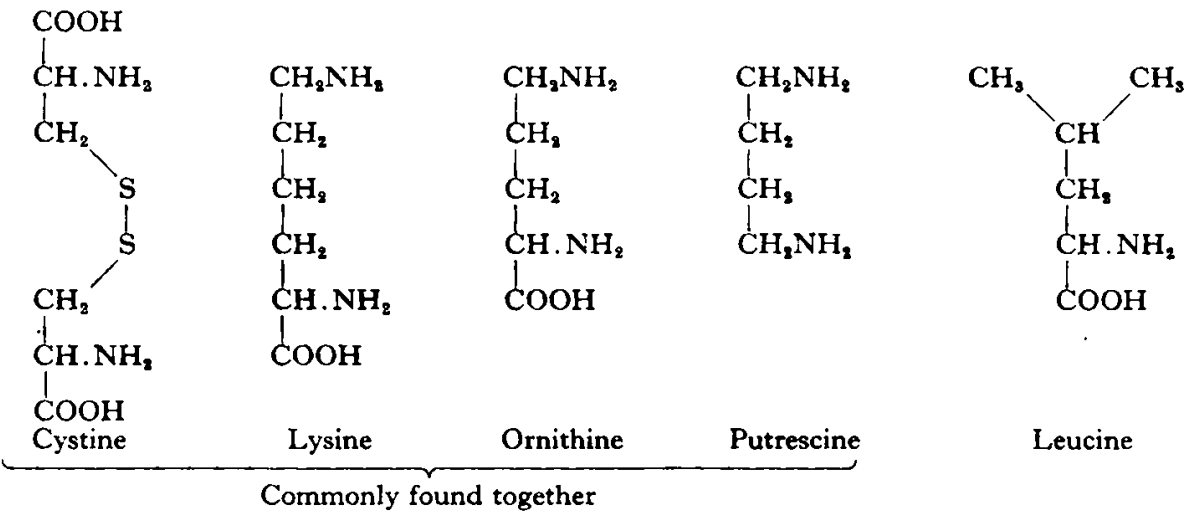

Fig. 3. Structural similarity of substances frequently found together in cystinuric urine.

- The effect of diet upon cystine excretion agrees well with this view. Thus, as already mentioned, the urinary excretion of cystine is raised by the administration of cysteine or of methionine, but not of cystine, and chromatographic and microbiological analysis has shown that the first two substances cause a rise in the plasma-cystine level, whereas cystine itself, presumably owing to very slow absorption, does not. The administration of certain amino-acids not containing sulphur also raises the level of cystine excretion by the cystinuric. Thus leucine raises the urinary cystine level (presumably by competing for absorption at the same site) without having any effect upon excretion of sulphate or methionine. When cystine is given together with methionine, a large increase occurs in its excretion. In harmony with the renal theory of cystinuria is the fact that glycine administration has little effect upon cystine output, although it raises endogenous nitrogen metabolism in general.

\section{Alcaptonuria, phenylketonuria and tyrosinosis}

Up to the present time, three inborn errors have been described which affect the metabolism of the aromatic amino-acids, phenylalanine and tyrosine. These conditions are known respectively as alcaptonuria, phenylketonuria and tyrosinosis. There is good evidence that each is associated with an interruption of a metabolic pathway due to the congenital absence of some particular enzyme, as shown in Fig. 4.

Alcaptonuria. In alcaptonuria, the sufferer excretes the substance, homogentisic acid, in the urine, which rapidly darkens in air owing to the oxidation and polymerization of the homogentisic acid to melanin-like material. Assuming that homogentisic acid is a normal intermediate in phenylalanine and tyrosine katabolism, it would thus appear that the block has occurred in the final stage, at which opening of the benzene ring is accomplished. Recent work by Lerner (1949) and others, using radioactive substrates, has thrown further light upon the ultimate stages of aromatic amino-acid metabolism as indicated in Fig. 5. With liver slices, phenylalanine was degraded to 
acetoacetic acid and malic acid, the former including two carbon atoms of the side chain, and these results are well explained by assuming that homogentisic acid is their immediate precursor.<smiles>NC(C(=O)O)C(N)C1CCC(O)CC1</smiles>

Phenylalanine<smiles>[Te]C[Te]</smiles>

$\square$<smiles>C=C(C)C(=O)O</smiles>

Phenylpyruvic acid
A p-Hydroxyphenylpyruvic acid

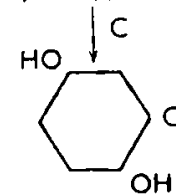

Interruption at:
A Phenylketonuria
B Albinism
C Tyrosinosis
D Alcaptonuria

$$
\text { r }
$$

2:5-Dihydroxyphenylpyruvic acid
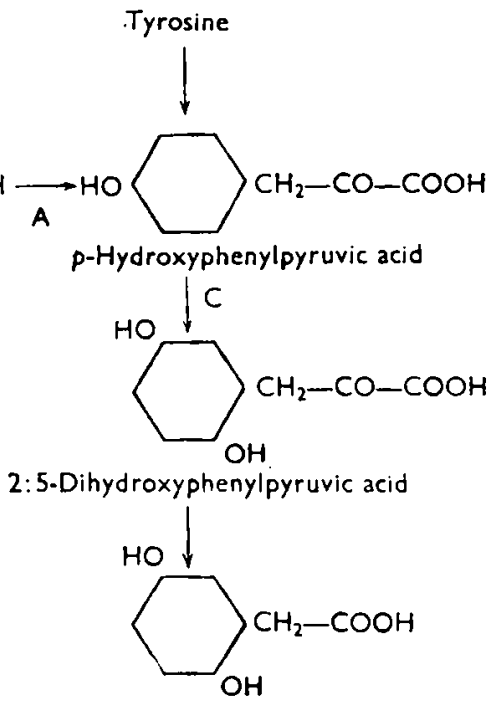

Homogentisic
$\mathrm{CO}_{2}+\mathrm{H}_{2} \mathrm{O}$
3:4-Dihydroxyphenylalanine

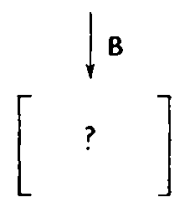

Melanin

Fig. 4. Metabolic pathways of aromatic amino-acids in man. Based on Haldane (194I).

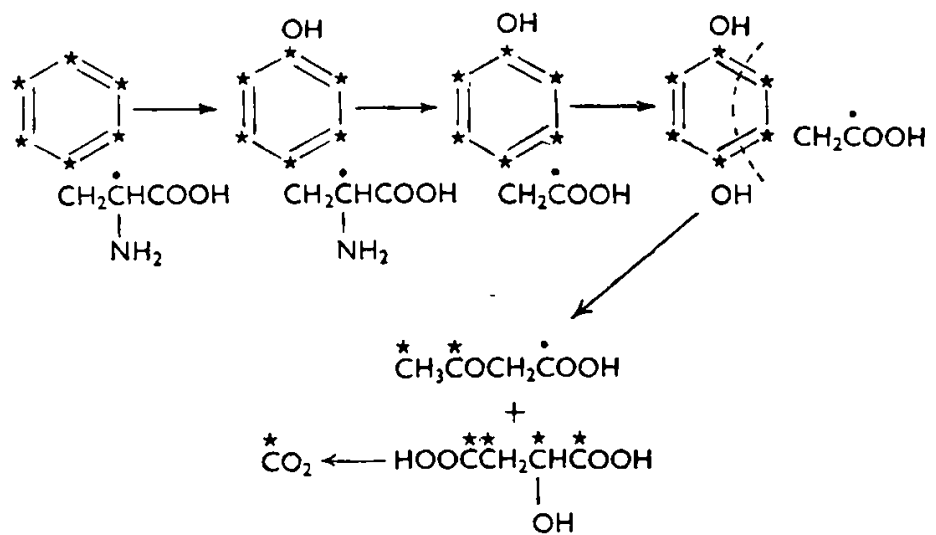

Fig. 5. Metabolism of phenylalanine, labelled by ${ }^{14} \mathrm{C}(*)$ in the ring and by ${ }^{18} \mathrm{C}(\bullet)$ in the $\alpha$ position of the side chain, by liver slices. From Lerner (1949). 
To what extent the metabolic block in alcaptonuria approaches completeness has been investigated by nutritional experiments in which the phenylalanine and tyrosine content of the diet has been compared with the urinary output of homogentisic acid both on a normal mixed diet and after artificial loading with one or other aromatic amino-acid. The most recent of such experiments by Neuberger, Rimington \& Wilson (1947), who used improved analytical methods, shows that the conversion to homogentisic acid may be over $80 \%$ but the existence of a minor alternative metabolic pathway cannot be denied. It was also found that the level of homogentisic-acid excretion remains uninfluenced by the administration of cysteine or of ascorbic acid in large doses. This is a point of particular importance since experiments upon normal animals by Sealock \& Silberstein (1940) and Sealock, Perkinson \& Basinski (194I) have shown that under the combined stress of ascorbic-acid deficiency and loading with excessive amounts of phenylalanine or tyrosine, excretion of homogentisic acid in the urine can be made to occur. Experimental homogentisic aciduria must be sharply differentiated from true alcaptonuria, however, since in the former condition other aromatic acids such as $p$-hydroxyphenyl pyruvic acid are also excreted in the urine. These were not found in alcaptonuria. Diets low in protein (Neuberger \& Webster, 1947) or deficient in cysteine and methionine (Glynn, Himsworth \& Neuberger, 1945) were found to induce homogentisic-acid excretion in rats, even on a normal intake of aromatic amino-acids.

Concerning the effect of diet upon the true inborn metabolic error, all that we can say is that the output of homogentisic acid by the affected subject rises or falls in sympathy with the quantity of aromatic amino-acids in the diet. No agent is known capable of influencing this excretion, although ascorbic acid by virtue of its reducing action, or diets leading to acidaemia, will delay the discoloration of the urine which occurs after it is passed. (See, however, Hürthle (1930).)

Phenylketonuria. Phenylketonuria is known by the synonyms 'Fölling's disease' and 'phenylpyruvic oligophrenia'. It is characterized by the urinary excretion of phenylpyruvic acid, is inherited as a recessive character (Penrose, 1935) and the subjects are all of low intelligence, although physically well-developed.

The quantity of phenylpyruvic acid excreted is comparatively small ( $1 \cdot 0-1 \cdot 5 \mathrm{~g} . /$ day) corresponding to approximately half the daily intake of phenylalanine. Observations by Dann, Marples \& Levine (1943), Fölling (1934), Jervis (1937), and their associates and more recently by Prescott, Borek, Brecher \& Waelsch (1949), show that the blood in this condition contains amounts of phenylalanine up to thirty-six times the normal, but no phenylpyruvic acid. In the urine, on the other hand, they did not find any phenylalanine although phenylpyruvic acid was present. We may best interpret these findings by concluding that the primary fault is an inability to metabolize phenylalanine by hydroxylation to tyrosine, as Jervis (1947) has indeed demonstrated, and that phenylalanine therefore accumulates in the blood. During its passage through the kidney, it is transformed into phenyl pyruvic acid which is then excreted (see Fig. 4).

Fölling (1934), the discoverer of this anomaly, advanced the hypothesis that the error consisted of an abnormal racemization of phenylalanine, the $\mathrm{D}$-isomer being produced and not further metabolized. Penrose \& Quastel (1937) preferred the inter- 
pretation that the patient was unable to break down the benzene ring of the keto-acid, but Jervis (1947) has recently brought forward conclusive evidence to show that it is the first stage in phenylalanine metabolism that affected persons are unable to perform, namely the introduction of the p-hydroxyl group into the benzene ring to form tyrosine. Tyrosine itself can be dealt with normally. Prescott et al. (1949) have confirmed this and have shown that no D-phenylalanine can be detected in the plasma of phenylketonurics.

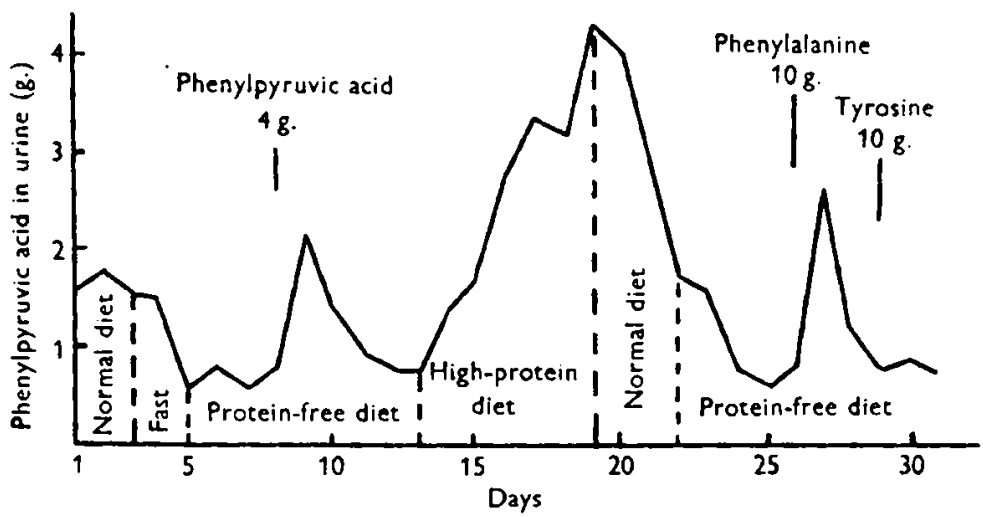

Fig. 6. Urinary output of phenylpyruvic acid in various feeding experiments in a case of phenylpyruvic oligophrenia. After Jervis (1937).

It would appear that, apart from the work of Jervis (1937) and Penrose \& Quastel (1937) who administered single doses of the amino-acid to their patients, no extended balance experiments have been performed in which the output of phenylpyruvic acid is compared with the level of phenylalanine intake. 'The authors cited found a fall in urinary phenylpyruvic-acid excretion to follow the institution of a low-protein diet and, as already noted, they estimated the percentage of phenylalanine metabolized by this route to be not greater than about $5^{\circ}$. What alternative pathways exist is unknown (Fig. 6).

'There is one aspect of this disease which I think may be important from a dietary therapeutic point of view. Sufferers from phenylpyruvic aciduria are all mentally deficient, and it is clearly important to inquire whether this biochemical lesion is one directly affecting the development or normal functioning of the nervous system, or whether the psychic abnormalities originate from other causes.

Since tyrosine is metabolized normally by the phenylketonuric, tyrosine deficiency as a cause of the nervous lesions may be excluded. Phenylalanine is present in the plasma in abundance and it is possible either that the cells of the nervous system normally utilize this amino-acid for the production of some essential $p$-hydroxylated derivative, the synthesis of which the affected organism is unable to carry out, or, alternatively, that phenylalanine when present in the plasma in high concentration is actually toxic. 'Toxicity might be exerted directly upon the brain cells or indirectly by preventing, through competition, the absorption by them of other amino-acids or related essential nutrients. 
Table 2. Average weekly intake of foods and nutrients per diet-head arranged according to income

$$
\text { Income ro-20s./head/week }
$$

Income 20-3os./head/week

Income over 30 s./head/week

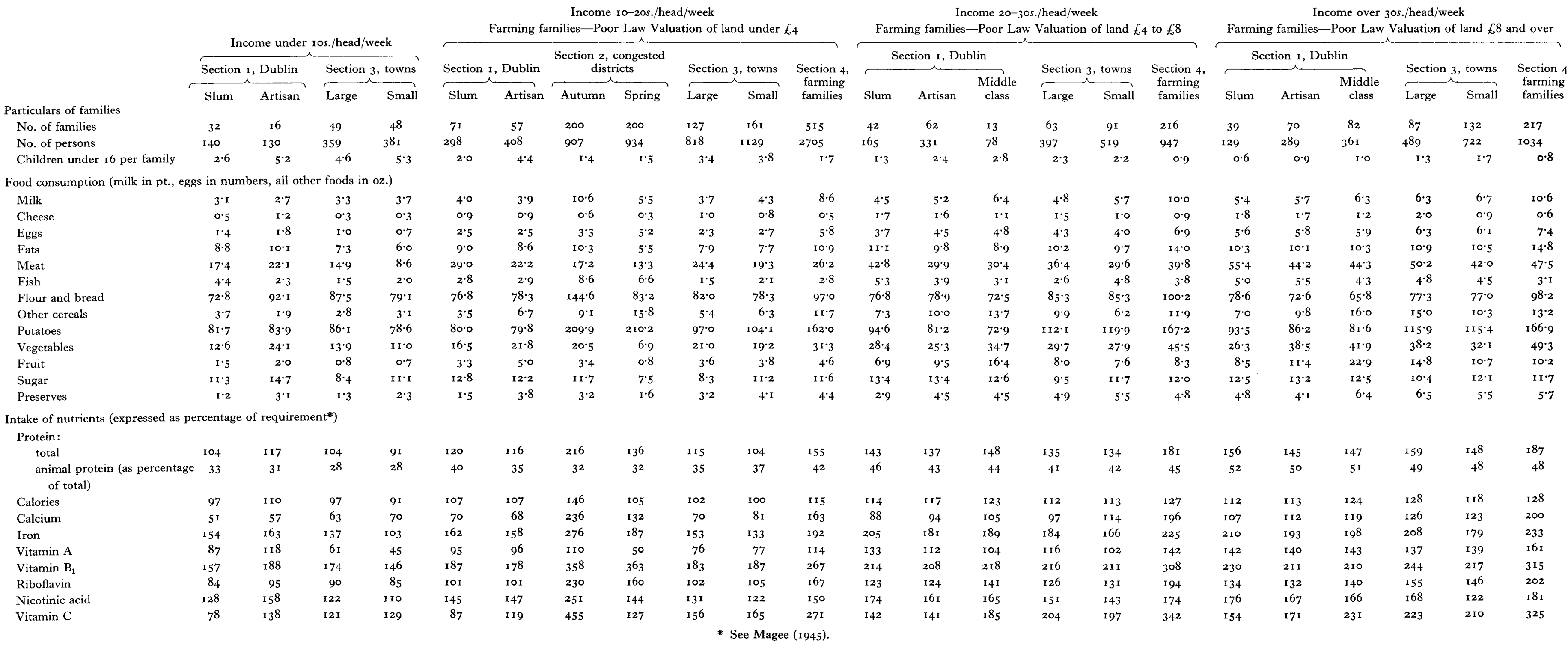


For this reason it might be profitable to carry out experiments upon sufferers from phenylketonuria in which the intake of phenylalanine-containing foods is maintained at the minimum for long periods. Similarly, the effect could be studied of high plasmaconcentrations of phenylalanine upon normal experimental animals to determine the type of lesion which occurs as a result of such a diet or the lesions produced by the metabolic antagonist, $\beta$-2-thienyl-DL-alanine (Ferger $\&$ du Vigneaud, 1949). This type of investigation is in fact already envisaged by $\mathrm{Dr}$ Dent and his associates.

The suggestion that an amino-acid might exert, when present in concentrations greatly exceeding those in which it is normally present, a deleterious influence upon a cell is not without some support from the literature. Thus the toxic action of DL-serine upon the kidney has been closely studied (Fishman \& Artom, 1942) and reports show that even a simple substance like glycine can cause illness and death when given at levels of the order of $0.8-8 \mathrm{~g} . / \mathrm{kg}$. to guinea-pigs ( $\mathrm{Ni}, 1937)$. With the latter substance, two types of symptoms were observed, either a loss of tone and paralysis of the skeletal muscles which were probably of central nervous origin since the reflex arcs, peripheral sensory cutaneous nerves, lower motor neurones and myoneural junctions remained normally functional, or a persistent tendency to perambulate in circles regardless of obstacles placed in the animals' path. Both these effects strongly suggest an interference with the normal functioning of the nervous system. Riker \& Gold (1942) have noted, in addition, in cats, complete dilatation of the pupil and loss of reaction to light after the administration of glycine.

Tyrosinosis. The third inborn error of metabolism affecting the aromatic amino-acids, namely tyrosinosis, may be summarily dismissed, since only a single case of this condition has so far been described (Medes, 1932) and there is no evidence, therefore, as to its familial nature.

The individual in question appeared to be unable to metabolize tyrosine beyond the stage of $p$-hydroxyphenylpyruvic acid which he excreted in his urine from his endogenous metabolism at the rate of about $\mathrm{x} \cdot 6 \mathrm{~g}$./day.

Raising the level of tyrosin intake either in protein or as the amino-acid itself increased the excretion of $p$-hydroxyphenylpyruvic acid but, after high loading with tyrosine, other substances such as $p$-hydroxyphenyllactic acid and 3:4-dihydroxyphenylalanine also appeared in the urine (see Fig. 4).

Of particular interest is the fact that administration of phenylalanine led to the excretion of tyrosine, $p$-hydroxyphenylpyruvic acid and of traces of the corresponding lactic acid, but the result was neither so prompt nor so marked as after tyrosine ingestion. This evidence supports the view that, whereas phenylalanine is normally converted in part into tyrosine, other metabolic pathways for the disposal of this amino-acid do exist.

That Medes's patient was well able to effect the final oxidation of the aromatic ring was demonstrated by the fact that when given homogentisic acid he disposed of it normally and the concentration of $p$-hydroxyphenylpyruvic acid in his urine suffered no change. 


\section{Familial methaemoglobinaemia}

My last example is an inborn error of metabolism which is susceptible to dietetic therapeutic treatment although the biochemical error is of such a nature that this is only possible by opening up alternative metabolic pathways.

The normal erythrocyte contains a system capable of restoring methaemoglobin to haemoglobin or oxyhaemoglobin. Thus, if intracellular methaemoglobin formation is induced by the action of nitrite or by other suitable means, and the red cells are then

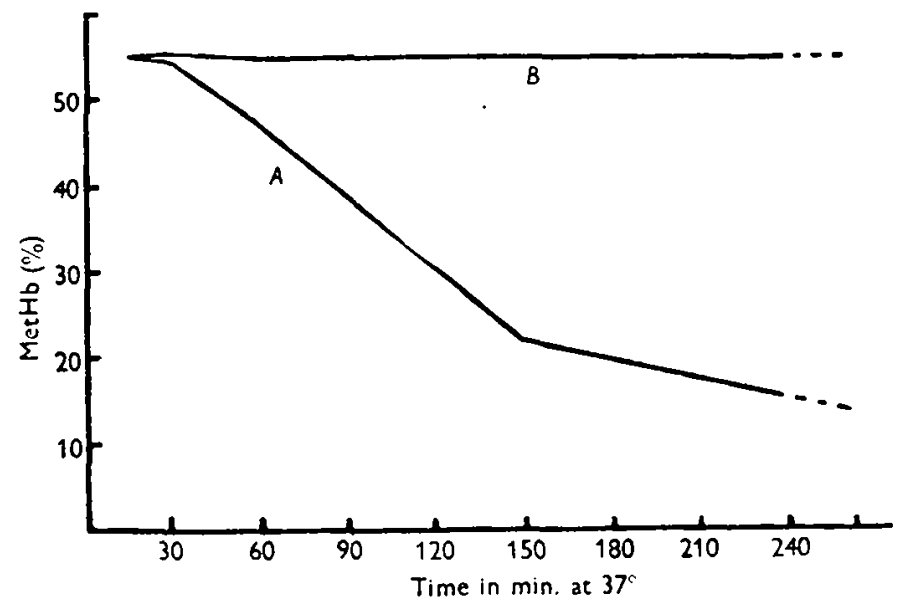

Fig. 7. Enzymic intracellular reversion of methaemoglobin to haemoglobin and its inhibition. From Drabkin (1948). $A$ : glucose alone, glucose $+\mathrm{NaF}+$ pyruvate. $B$ : glucose $+\mathrm{NaF}$, glucose + iodoacetate, glucose + iodoacetate + pyruvate. (Haemolysis.)

observed in vivo or in vitro, a progressive and rapid decline of the oxidized pigment is seen to occur. Drabkin ( 1948 ) has shown that the reduction is coupled with the breakdown of glucose and can be inhibited by the addition of fluoride, iodoacetate or any substance which effectively blocks the course of glucolysis. Addition of pyruvate under such circumstances will, however, restore the ability to convert methaemoglobin to haemoglobin (see Fig. 7).

The erythrocytes of sufferers from familial methaemoglobinaemia contain a considerable proportion of their blood pigment in the form of methaemoglobin and there is little or no tendency for this pigment to disappear in the shed blood even after addition of glucose or of lactate. Gibson (1948) has recently completed a most interesting study of the condition and has found that in such individuals there is deficiency in the red cells of a substance designated 'coenzyme factor I' which may be a flavoprotein and which acts as a link in the chain in the normal erythrocyte between coenzyme I and methaemoglobin. It is, in fact, probable that this is the mechanism which normally prevents the accumulation of methaemoglobin in the cells, if the view of Peters \& Van Slyke (1931) is adopted that methaemoglobin is constantly being formed in the blood.

Since methylene blue was known from the work of Cox \& Wendel (1942) to accelerate the disappearance of drug methaemoglobinaemias when injected in vivo, its 
effect was tried in vitro with normal methaemoglobin-containing cells in the presence of glucose or of lactate. The rate of reduction was markcdly accelerated, but with methaemoglobin-containing cells from a case of familial methaemoglobinaemia the result was in striking contrast. The rate of reduction was accelerated as in normal cells by methylene blue and glucose but methylene blue and lactate had no effect. Gibson interprets these facts as follows: the reduction of methaemoglobin is assumed to take

A

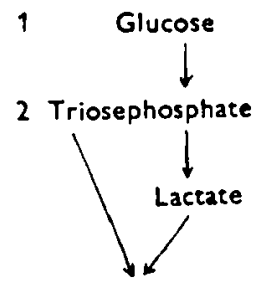

3 Dehydrogenases

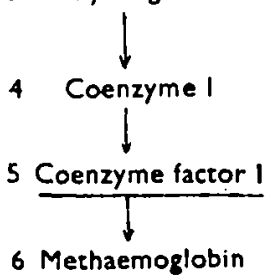

B

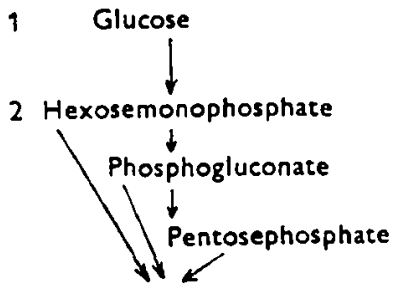

3 Dehydrogenases

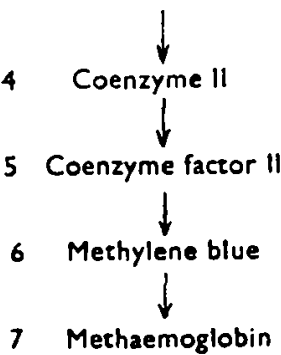

Fig. 8. Diagrammatic scheme of the reactions taking place in the reduction of methaemoglobin in erythrocytes. Column A, reactions occurring in the absence of methylene blue; column B, in its presence. In cases of idiopathic methaemoglobinaemia where there is a deficiency of coenzyme factor I the reactions in column A do not occur and methaemoglobin reduction is very slow. From Gibson (1948).

place normally according to scheme A (Fig. 8), whereby either triosephosphate or lactate serves as the substrate for the dehydrogenase which passes hydrogen to methaemoglobin via coenzyme I and the coenzyme factor I. In the absence of this latter factor in familial methaemoglobinaemia, the chain linking lactate with methaemoglobin is broken and no reduction of the pigment can therefore take place. In the presence of glucose and methylene blue, however, an alternative pathway is opened up which proceeds via coenzyme II and coenzyme factor II. The latter will reduce methylene blue to leuco-methylene blue which in turn reduces methaemoglobin to the ferrous state. 'The system (scheme B) is therefore catalytic, and removal of the methaemoglobin from the red cells may be accomplished.

If one may consider methylene-blue administration as a dietetic procedure then we have here an example of the treatment of an inborn metabolic error by a therapeutic dietetic measure. Not only methylene blue, but also ascorbic acid, however, will act as a reducing agent for methaemoglobin in this disease and to the classification of ascorbic acid as a dietary constituent there can be no objection. 


\section{REFERENCES}

Abderhalden, E. (1903). Hoppe-Seyl. Z. 38, 557.

Brand, E., Cahill, G. F. \& Harris, M. M. (1935). Y. biol. Chem. rog, 69.

Cox, W. W. \& Wendel, W. B. (1942). F. biol. Chem. 143, 331.

Dann, M., Marples, E. \& Levine, S. Z. (1943). F. clin. Invest. 22, 87.

Dent, C. E. (19+9). In Partition Chromatography (Biochem. Soc. Symposium, no. 3), p. 34. Cambridge: The University Press.

Drabkin, D. L. (1 948). Fed. Proc. 7, 483.

Ferger, M. F. \& du Vigneaud, V. (1949). Y. biol. Chem. 179, 6r.

Fishman, W. H. \& Artom, C. (1942). F. biol. Chem. 145, 345.

Fölling, A. (1934). Hoppe-Seyl. Z. 227, i 69.

Garrod, A. E. (1923). Inborn Errors of Metabolism, 2nd ed. London: Hodder and Stoughton.

Gibson, Q. H. (1948). Biochem. F. 42, 13.

Glynn, I.. E., Ilimsworth, H. P. \& Neuberger, A. (1945). Brit. F. exp. Path. 26, 326.

Haldane, J. B. S. (194I). Neze Paths in Genetics. I ondon: Allen and Unwin.

Hürthle, R. (1930). Z. klin. Med. I14, 144.

Jervis, G. A. (1937). Arch. Neurol. Psychiat., Lond., 38, 944.

Jervis, G. A. (1947). F. biol. Chem. 169, 65x.

Lerner, A. B. (1949). J. biol. Chem. 181, 281.

Medes, G. (1932). Biochem. $7.26,9$ I 7.

Neuberger, A., Rimington, C. \& Wilson, J. M. G. (1947). Biochem. F. 41, 438.

Neuberger, A. \& Webster, T. A. (1947). Biochem. F. 41, 449.

Ni, T. G. (1937). Chin. J. Physiol. 12, 301.

Penrose, I.. \& Quastel, J. H. (1937). Biochem. J. 31, 266.

Penrose, L. S. (1935). Lancet, 229, 192.

Peters, J. P. \& Van Slyke, D. D. ( 93 I). Quantitative Clinical Chemistry. Vol. I. Interpretations, p. 63 I. London: Baillière, Tindall and Cox.

Prescott, B. A., Borek, E., Brecher, A. \& Waclsch, H. (1949). F. biol. Chem. 181, 273.

Riker, W. F. \& Gold, H. (1 942). F. Amer. pharm. Ass. 31, 306.

Sealock, R. R., Perkinson, J. D. \& Basinski, D. H. (1941). F. biol. Chem. 140, I 53.

Sealock, R. R. \& Silberstein, H. E. (1940). J. biol. Chem. 135, 25 I.

\section{Vitamin $B_{12}$ and other Dietary Factors in Megaloblastic Anaemias}

\section{By C. C. Unglfy, Royal Victoria Infirmary, Nerucastle upon Tyne}

The megaloblastic anaemias to which I refer fall into two groups: pernicious anaemia, in which gastric atrophy and permanent loss of Castle's intrinsic factor leads to deficient absorption of vitamin $B_{12}$, and non-Addisonian megaloblastic anaemias, e.g. those associated with pregnancy and intestinal disorders where a different mechanism is at work.

\section{Pernicious anaemia}

The effects of parenteral administration of vitamin $B_{12}$ in pernicious anaemia have already been described (Ungley, I949 $a$ ) and I need only recall a few salient points.

Single doses of $10 \mu \mathrm{g}$. or more produced, on the average, a maximal reticulocyte response. A better yardstick, however, is the increase of red blood cells in 15 days. Here, Io $\mu \mathrm{g}$. produced a response up to the average standard of Della Vida \& Dyke (1942), but we found that doubling the dose anywhere in the range from 5 to 80 , or even $160 \mu \mathrm{g}$., produced a constant increase in response. About $80 \%$ of the total increase of red blood cells in 5 days occurred in the first ro days.

These findings form a useful basis for comparison, e.g. in assessing the efficacy of vitamin $B_{12}$ in other types of megaloblastic anaemia and for comparing vitamin $B_{12}$ from liver with a similar crystalline vitamin obtained from Streptomyces griseus. 